\title{
SUSTAINABILITY IN THE MEETINGS INDUSTRY
}

\author{
Vanja Pavlukovicín, \\ Milica Vujičić', \\ James Kennell2, \\ Marija Cimbaljević ${ }^{1}$ \\ ${ }^{1}$ University of Novi Sad, \\ Faculty of Sciences, \\ Department of Geography, \\ Tourism and Hotel Management, \\ Novi Sad, Serbia \\ 2University of Greenwich, \\ Faculty of Business, \\ Department of Marketing, \\ Events and Tourism, \\ UK
}

\begin{abstract}
:
The meetings industry, also known as MICE and as business travel and tourism, is comprised of association conventions and congresses, corporate meetings, incentives and exhibitions. It is an important sector of the global tourism industry and often plays a leading role in tourism development in emerging destinations, including Serbia. The meetings industry is affected by several global megatrends such as globalisation, demographic change, technology, safety, sustainability, and recently by the corona virus pandemic. Although there is an increasing focus on sustainability more widely, there has been little academic research on this topic in the meetings industry compared to the existing body of research on sustainability in the tourism and hospitality industries. Therefore, this paper aims to raise awareness of the importance of this topic with both academics and industry practitioners, with the focus on developing countries, such as Serbia. Moreover, the paper presents some examples of best practices in sustainability in the meetings industry, to inspire all industry stakeholders to be responsible and innovative in these challenging times.
\end{abstract}

\section{Keywords:}

sustainability, the meetings industry, sustainable events, sustainable destinations.

\section{INTRODUCTION}

The meetings industry is an important and fast-growing sector of the global tourism industry (World Travel and Tourism Council, 2017; Han et al., 2019; Pavluković and Cimbaljević, 2020). Sometimes referred to as the "MICE" sector or business tourism, it is traditionally composed of four components - association conventions and congresses, corporate meetings, incentives and exhibitions, although this has also been widened to include networking events and hybrid forms of corporate events (Bladen et al., 2017). The meetings industry includes corporate, association and government meetings, corporate incentives, seminars, congresses, conferences, conventions, exhibitions and fairs (United Nations World Tourism Organization [UNWTO] and European Travel Commission [ETC], 2015). This industry involves a broad range of organisers and suppliers involved in the planning and delivery of meetings, which are organized to achieve different goals (e.g. professional, business, cultural or academic).
Correspondence:

Vanja Pavluković

e-mail:

vanja.dragicevic@dgt.uns.ac.rs 
Destinations around the world have recognised the numerous benefits of hosting meetings and other events (Han and Hwang, 2017). In particular, emerging destinations have made significant capital investments in developing the infrastructure necessary for the meetings industry (Presbury and Edwards, 2005; Pavluković and Cimbaljević, 2020). Consequently, competition between destinations has become vigorous (Beardsley et al., 2019; UNWTO and ETC, 2015). Furthermore, several global megatrends are shaping the future of the meetings and events industry, such as globalisation, demographic change, technology, safety, sustainability (Davidson, 2018) and recently, the corona virus pandemic. There is an increasing focus on sustainability and responsible, sustainable practices (sometimes referred as "green" practices) in the meetings and events industry (Hall, 2012; Merrilees and Marles, 2011), summarised by Zifkos (2015) as 'sustainability everywhere'. To attract the attention of meeting planners and event attendees, and to outperform their competitors, destinations, convention bureaus, venues and professional conference organisers (PCOs) have recognised the need to implement sustainability principles in their strategies and quotidian activities. However, little academic research dealing with sustainability in the meetings industry has been published, when compared to the large body of research on sustainability in tourism and hospitality (Hall, 2012; Merrilees and Marles, 2011; Turner and Kennell, 2018). Therefore, this paper aims to raise awareness of the importance of incorporating sustainability in the meetings industry among academics and meetings industry practitioners, specifically in developing countries, such as Serbia.

\section{THE CONCEPT OF SUSTAINABILITY}

Sustainability principles refer to the environmental, economic and socio-cultural aspects of tourism development, and a suitable balance must be established between these three dimensions to guarantee long-term sustainability (UNEP, 2005; dos Anjos and Kennell, 2019). In the wider general business environment, the three P's (Planet, People and Profit) approach to sustainability are widely known. Similarly, the three E's model (Economic, Environmental and Equity) or the "three-legged stool" has also been used to explain the concept of sustainability (Turner and Kennell, 2018). Various competing definitions of this concept emphasise the importance of different perspectives on sustainability and their interconnectedness. In 2015, all United Nations Member States adopted the 2030 Agenda for Sustainable Development, with its 17 Sustainable Development Goals (SDGs) and called for action on the global, local and individual level towards sustainable development for all (United Nations, 2015).

Sustainability is a relatively new perspective within events management (Turner and Kennell, 2018; Wickham and French, 2020), in particular in business events. It is a concept that is increasingly incorporated into event management and planning (Hall, 2012), and events management education (Millar and Park, 2018). The emerging sustainable events management literature has primarily dealt with sustainability in terms of environmental impacts (Turner and Kennell, 2018) or the greening of the industry. Therefore, terms such as green destinations, green events, and green venues are widely accepted in practice as well as in the academic literature and refer mostly to the environmental aspect of sustainability. Being sustainable, in a way, means the greening of everything: greening technology, greening different sectors, changes in terms of goods/services, processes, and greening every type of policy (Mair and Jago, 2010: 78).

Greening of the tourism industry, as well as the meetings industry, is one of the most important consumer trends (UNWTO, 2019), which should not be ignored by destination management companies and service providers. It can involve practices including, inter alia, paperless meetings, zero plastic, zero-waste meetings, recycling, choosing meeting destinations with good public transport, choosing green venues or eco-certified venues, as well as using green suppliers. The benefits of incorporating sustainability into events can be various, such as environmental improvements and cost savings, creating a positive image for the event and host destination, social benefits for the local community, raising awareness on the importance of incorporating sustainability in quotidian business activities etc. (UNEP, 2012).

A sustainable event is one designed, organised and implemented in a way that minimises potential negative impacts and leaves a beneficial legacy for the host community and all involved (UNEP, 2012, p.1). A sustainable event balances environmental, social and economic responsibilities. Merrilees and Marles (2011) write about environmental sustainability as a core part of green events brands. 
This aspect of sustainability refers to low-emission transport and mobility, waste reduction, reuse and recycling, water and energy efficiency. Economic sustainability means profit and cost savings, while the social aspect of sustainability highlights the fair use of human resources and a healthy and safe workplace for all involved, respecting human rights, the inclusion of minorities, respecting diversity, attention to equal opportunities, encouraging the involvement of the local community, sourcing goods and services locally, and employing local people (UNEP, 2012, p.2). Sustainable events are usually organised based on the 4 R principles - Reduce, Reuse, Recycle and Raise awareness (Lee, 2001). They also include components of education, entertainment and experience.

Sustainability is not just about the environment and being "green", it is also about people and the local community, as well as economic benefits. Smith (2009) suggests that more attention to the social sustainability of events is needed. The beginning of the $21^{\text {st }}$ century has witnessed the growing interest of meeting planners in adding a social legacy dimension to meetings, particularly as younger participants (members of Generation $\mathrm{Y}$ ) want to give something back to the communities where their meetings take place. The social legacy of the meetings industry is one of the key trends driving the design of business events today. It relates to the people aspect of the three P's approach to sustainability and goes far beyond the greening of the meetings industry. It takes into account how a meeting impacts upon a local community and its economy. Examples of social legacy range from donation programs to local humanitarian organizations (food, cash or material donations) to becoming involved in local construction or renovation projects (e.g. for schools or kindergartens) (Davidson, 2009; Rogers, 2013). In the following section, some examples of best practices in sustainability in the meetings industry will be presented and discussed.

\section{THE IMPLEMENTATION OF THE SUSTAINABILITY CONCEPT IN THE MEETINGS INDUSTRY}

There is a growing interest within the leading international organisations in the field of tourism and the meetings industry in supporting sustainable practices and introducing sustainability standards, along with indicators for measuring the sustainability performance of destinations, venues, and individual events (Guo et al., 2019; Wise, 2020). In response to the growing interest in sustainability in tourism and the event industry, sustainability standards and events labelling at international, as well as national levels, have been adopted. In 2012, the International Organization for Standardization (ISO) created a sustainable event standard (ISO20121) for the London 2012 Olympic Games. The standard was developed following the successful adoption of the BS8901 standard in the UK (Bladen, 2017; Hall, 2012). It specifies requirements for an event sustainability management system for any type of event or event-related activity. To achieve ISO 20121, an organisation will need to demonstrate that it has considered within its management system all key financial, economic, social and environmental issues relevant to its operations and focusing solely on environmental issues will not be sufficient for accreditation (International Organization for Standardization (ISO), 2020). Also, there are others meetings related standards which are globally relevant, such as Events Industry Council Sustainable Event Standards, formerly APEX/ASTM Environmentally Sustainable Meeting Standards (see Events Industry Council, 2020).

In response to an increasing focus on sustainable practices in the meetings industry, leading destinations in the European as well as global meetings market are working to make their locations more competitive and attractive to event planners and stakeholders. In this context, Germany and Austria developed their own national sustainability standards, to certify the environmentally conscious as well as socially responsible management of meetings. In 2010, the Austrian Eco-label for Green Meetings and Green Events was introduced, to reduce the negative environmental impacts and ecological footprint of events organised in Austria, and to reinforce social responsibility (Sustain Europe, 2017). According to the German Convention Bureau, nearly $40 \%$ of German event venues have already implemented a sustainability management system, and numerous service providers hold certificates from organisations such as Green Globe or ISO. The sustainability code in the German events sector called "Rightandfair", which was initiated in May 2012, represents a voluntary self-commitment to corporate responsibility for sustainability when organising and running events. Since then, over 400 associations and their member companies from all areas of the industry have subscribed to it (German Convention Bureau, 2020). 
In Serbia, there are four hotels that have received international Green Key eco-certificate, which demonstrates their commitment to implementing sustainable practices in their business and every-day operations (Environmental ambassadors for sustainable development, 2020).

In a market where consumers are willing to pay more for sustainable brands (Lopez-Sanchez and Pulido Fernandez, 2017; Slocum et al, 2018), and where service providers proclaim their sustainability commitment, third party certification is often crucial for gaining consumer confidence. The percentage of certified hotels, conference centres and other venues, as well as PCOs and other service providers in the meetings industry, and their reporting against sustainability performance indicators, clearly communicate their commitment, as well of that of the destination, to sustainability for their clients, the supply chain and the employees of an organisation. Although greening venues and other service providers requires additional investments and costs, in the long run these investments provide financial advantages and support from local community, as well as more engaged and satisfied staff, customers and meetings participants.

The German Convention Bureau, as an example of good practice in the field of implementing sustainability in the meetings sector, provides a simple set of recommendations for sustainable events. Namely, event organisers should state that sustainability is a priority in all enquiries and brief all staff accordingly. Regarding venue and service provider selection, green-certified venues and local suppliers and products should be used as much as possible. "Paperless" and "zero plastic" events should be supported, not only saving costs, but also reducing the negative environmental impacts of the event. The Bureau recommends organisers adopt carbon-neutral policies and promote the usage of public transport to venues. Additionally, communicating sustainability actions to participants and the broader public, as well as encouraging more sustainable behaviour among participants and the local community, is an important aspect of a sustainable event (German Convention Bureau, 2020).

At the destination level, to improve sustainable development strategies and to achieve competitive advantage, destination management companies and/or convention bureaus should: integrate the UN sustainable development goals (SDGs) into their destination brand, support and promote the certification of sustainable management systems (such as ISO20121, or national certification standards), engage strategically with their stakeholders, promote local service providers, measure the positive and negative footprint of their local events and tourism sector, communicate about their destination's sustainability programme and report on social, economic and environmental impacts, strategies, and performance. To promote the sustainable growth of international meeting destinations, the Global Destination Sustainability Index (GDSI) was launched in 2015, the same year as the UN's 2030 Agenda for Sustainable Development. The GDSI is supported by two leading organisations in the meetings industry: the International Congress and Convention Association (ICCA) and IMEX, the leading trade fair for the industry. It benchmarks the performance of cities and convention bureaus across four key areas: city environmental strategy and infrastructure, city social sustainability performance, industry supplier support, and convention bureau strategy and initiatives. The 2019 GDSI results demonstrate that convention bureaus have improved their performance on sustainability, with many examples of sustainability leadership, and initiatives and best practices from multiple destinations, including Copenhagen, Glasgow, Sydney, Monaco and Ljubljana. For example, in 2019, Ljubljana entered the Global Top 100 Sustainable Destinations list thanks to its initiative called the Locally Grown Food Exchange, aimed to encourage buyers such as hotels and restaurants to purchase seasonal ingredients from local producers (International Congress and Convention Association, 2020; GDSI, 2019). Another interesting example of the implementation of sustainable tourism strategy comes from Monaco, which is perceived primarily as a luxury destination. Since 2010 Monaco has been working on the development of a responsible tourism and events sector, with sustainability as a part of the luxury experience. In this context, the Monaco Government Tourist and Convention Authority created the campaign under the slogan "Green is the New Glam", to emphasize that it is no longer possible to be luxury ("glam") without being responsible ("green"). The focus of this campaign is generation $\mathrm{Y}$, who are considered to be the most environmentally and socially conscious generation. In May 2019, the Convention Bureau launched a new campaign, "Business is Green", targeting corporations and associations with a commitment to sustainability (GDSI, 2019).

In contrast to established meeting destinations, the literature, as well as many meetings industry practitioners, highlight the attractiveness of emerging destinations, such as Serbia, for holding meetings (UNWTO and ETC, 2015). To attract the attention of meeting planners and attendees, and to outperform the competitors, these destinations should implement sustainability principles in their tourism development strategies and every-day practice. 


\section{CONCLUSION}

The primary purpose of this paper was to raise awareness on the topic of sustainability in the meetings industry, particularly in developing economies, such as Serbia. Thus, it contributes to the body of knowledge on this important topic, as well as to practice.

Members of generation $\mathrm{Y}$, who represent a large and growing cohort in the meetings industry are considered to be the most environmentally and socially conscious generations, willing to pay more for sustainability brands (Bochert et al., 2017; Davidson, 2011). Therefore, embracing sustainability and "green standards" should be high priorities for destinations and meeting planners, to cater appropriately for the needs of the event's audience (especially generation $\mathrm{Y}$ ), as the industry recovers from the effects of the global pandemic. This will enable a destination or venue to differentiate itself in the marketplace and hence improve their chance of winning new business. Organising sustainable events reduces their environmental impact, and brings numerous advantages to the main actors involved, such as financial benefits, positive reputation and improved image, and social benefits, contributing to positive event legacies. Moreover, sustainability is an important quality indicator in competition with other events and meetings destinations, which is confirmed each year by the GDSI. Incorporating these new perspectives on sustainability into the education of future meetings industry professionals and future meetings management practices is an important task for educators and leading international and national organisations in the industry.

Recently, the global corona virus pandemic has significantly affected the tourism and meetings industry. Finding a way to recover the sector is one of the greatest challenges for practitioners today. Most face-to-face events are cancelled or postponed, and meetings have been switched to online delivery. However, some industry experts and practitioners predict the rise of hybrid meetings and face-to-face meetings with a smaller number of participants, and it is important that these are developed in line with the mega trend of sustainability that will continue to influence the industry (Davidson, 2018). On a positive note, due to travel barriers and the corona virus pandemic, the impact of travelling to meetings is minimised. Moreover, challenges resulting from COVID-19 could be seen as opportunities for the industry's renaissance. In particular, with the use of technology, organizers can make meetings more international (virtual and/or hybrid events with global audience), innovative, more accessible (barrier-free events, open to all individuals, particularly to those with disabilities) and, finally, more sustainable. In the time of the global corona virus pandemic, the attention to sustainability became more important than ever.

This paper should be of interest to all stakeholders in the meeting industry, including convention bureaus, destination management companies, professional conference organisers (PCOs), meeting planners, venues and other service providers. Future research should include more empirical studies on sustainable events, sustainable destinations, the sustainability of events venues, measuring sustainable performance, the social aspects of sustainability as well as the impact of technology and virtual events on the "greening" of the meetings industry.

\section{REFERENCES}

Beardsley, M., Jung, S., Kim, H., \& Kim, Y.-S. (2019). Tourism Experiences during a Convention: A Case Study from South Korea. Tourism Analysis, 24(1), 81-86. DOI: 10.3727/108354219X15458295631981.

Bladen, C., Kennell, J., Abson, E. \& Wilde, N. (2017) Events Management: An Introduction, $2^{\text {nd }}$ Ed., London: Routledge.

Bochert, R., Cismaru, L., \& Foris, D. (2017). Connecting the members of generation Y to destination brands: A case study of the CUBIS project. Sustainability, 9(7), 1197. DOI: 10.3390/su9071197.

Davidson, R. (2009). Business tourism: providing a social legacy. Tourism Insights, (September).

Davidson, R. (2011). What Does Generation Y Want from Conferences and Incentive Programmes? Implications for the Business Tourism Industry. In Yeoman, I., Hsu, CHC. Smith, K. and Watson, S. (Eds.), Tourism and Demography(pp.115-129). Goodfellow, Oxford.

Davidson, R. (2018). Business events. London: Routledge.

dos Anjos, F. A., \& Kennell, J. (2019). Tourism, Governance and Sustainable Development. Sustainability, 11(16), 1-6. DOI: 10.3390/su11164257. 
Environmental ambassadors for sustainable development (2020). Zeleni ključ -međunarodna eko-sertifikacija turističkih objekata. Retrieved October 6, 2020, from http://ambassadors-env.com/project/zeleni-kljucmedunarodna-eko-sertifikacija-turistickih-objekata/

Events Industry Council (2020). Sustainability Standards and Registry. Retrieved November 22, 2020, from https://insights.eventscouncil.org/Sustainability/Sustainability-Standards-and-Registry

German Convention Bureau (GCB) (2020). Green Meetings made in Germany. Retrieved September 6, 2020, from https://www.gcb.de/trends-inspiration/green-meetings.html

Global Destination Sustainability Index (GDSI) (2019). Sustainable destination management trends, best practices and insights. A white paper. Retrieved September 6, 2020, from https://www.gds.earth/reports/

Guo, Y., Jiang, J., \& Li, S. (2019). A sustainable tourism policy research review. Sustainability, 11(11), 3187. DOI: $10.3390 /$ su11113187.

Hall, C. M. (2012). Sustainable mega-events: Beyond the myth of balanced approaches to mega-event sustainability. Event Management, 16(2), 119-131. DOI: 10.3727/152599512X13343565268294.

Han, H., \& Hwang, J. (2017). What motivates delegates' conservation behaviors while attending a convention? Journal of Travel \& Tourism Marketing, 34(1), 82-98. DOI: 10.1080/10548408.2015.1130111.

Han, H., Lee, S., Al-Ansi, A., Kim, H. C., Ryu, H. B., Kim, J. J., \& Kim, W. (2019). Convention Tourism and Sustainability: Exploring Influencing Factors on Delegate Green Behavior that Reduce Environmental Impacts. Sustainability, 11(14), 3903. DOI: 10.3390/su11143903.

International Congress and Convention Association (ICCA). Retrieved September 6, 2020, from www.iccaworld.org International Organization for Standardization (ISO). Retrieved September 6, 2020, from www.iso20121.org/

Lee, K. F. (2001). Sustainable tourism destinations: the importance of cleaner production. Journal of Cleaner Production, 9(4), 313-323. DOI: 10.1016/S0959-6526(00)00071-8.

Lopez-Sanchez, Y., \& Pulido-Fernández, J. I. (2017). Factors influencing the willingness to pay for sustainable tourism: a case of mass tourism destinations. International Journal of Sustainable Development \& World Ecology, 24(3), 262-275. DOI: 10.1080/13504509.2016.1203372.

Mair, J., \& Jago, L.(2010) The Development of a Conceptual Model of Greening in the Business Events Tourism Sector. Journal of Sustainable Tourism 18(1), 77-94. DOI: 10.1080/09669580903291007.

Merrilees, B., \& Marles, K. (2011). Green business events: profiling through a case study. Event management, 15(4), 361-372. DOI: 10.3727/152599511X13175676722609.

Millar, M., \& Park, S. Y. (2018). Industry professionals' perceptions of sustainability in meeting and event education. Journal of Teaching in Travel \& Tourism, 18(2), 123-137. DOI: 10.1080/15313220.2017.1416727.

Pavluković, V., \& Cimbaljević, M. (2020). Factors affecting conference participation decision-making. Journal of the Geographical Institute" Jovan Cvijic", SASA, 70(1), 31-43. DOI: 0.2298/IJGI2001031P.

Presbury, R., \& Edwards, D. C. (2005). Incorporating sustainability in meetings and event management education. International Journal of Event Management Research 1(1), 30-45.

Rogers, T. (2013). Conferences and conventions $3^{\text {rd }}$ edition: A global industry. Routledge, London.

Slocum, S. L., Jin, N. P., \& Cho, I. S. (2018). Willingness to Pay for Sustainable Food in the Meeting Planning Sector. Culinary Science \& Hospitality Research, 24(7), 153-161. DOI: 10.20878/cshr.2018.24.7.017.

Smith, A. (2009). Theorising the relationship between major sport events and social sustainability. Journal of Sport \& Tourism, 14(2-3), 109-120. DOI: 10.1080/14775080902965033.

Sustain Europe (2017). The Austrian Eco-label: Green Meetings \& Green Events. Retrieved September 15, 2020, from https://www.sustaineurope.com/the-austrian-eco-label-green-meetings---green-events.html

Turner, Z., \& Kennell, J. (2018). The role of sustainable events in the management of historic buildings. Sustainability, 10(11), 3884. DOI :10.3390/su10113884.

United Nations. (2015). Transforming Our World: The 2030 Agenda for Sustainable Development: Preamble and Declaration. Retrieved September 4, 2020 from https://sustainabledevelopment.un.org/post2015/ transformingourworld/publication

United Nations Environment Programme (UNEP) (2005). Making Tourism More Sustainable - A Guide for Policy Makers. Madrid, Spain: UNWTO

United Nations Environment Programme (UNEP) (2012). Sustainable Events Guide. Nairobi, Kenya.

United Nations World Tourism Organization \& European Travel Commission. (2015). The Decision-making Process of Meetings, Congresses, Conventions and Incentives Organizers. Madrid, Spain: UNWTO.

Wickham, M., Donnelly, T., \& French, L. (2020). Strategic sustainability management in the event sector. Event Management, 24(2-3). DOI: 10.3727/152599519X15506259856318. 
Wise, N. (2020). Urban and Rural Event Tourism and Sustainability: Exploring Economic, Social and Environmental Impacts. Sustainability, 12(14), 1-5. DOI: 10.3390/su12145712.

World Tourism Organization (UNWTO) (2019). International Tourism Highlights, 2019 Edition. UNWTO, Madrid.

World Travel \& Tourism Council. (2017). Maximising Opportunities for Business Travel Growth [Report]. Retrieved September 15, 2020, from https://www.wttc.org/publications/2017/p4g-white-paper-maximising-opportunities-for-business-travel-growth/

Zifkos, G. (2015). Sustainability everywhere: Problematising the "sustainable festival" phenomenon. Tourism Planning \& Development, 12(1), 6-19. DOI: 10.1080/21568316.2014.960600. 